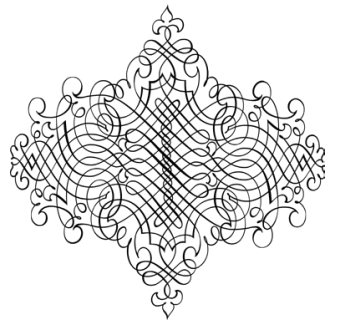

\author{
PoзAis 2.
}

ІНТЕРПРЕТОЛОГІЧНІ СТРАТЕГІЇ АОСЛІАНИЦЬКОÏ ПРАКТИКИ

УДК 78.087.681 «1850/1899» Рахманинов

DOI 10.34064 / khnum 1-5508

\title{
Днепровская Наталия
}

ORCID 0000-0002-0699-5331

\section{С. Рахманинов. «Шесть хоров для детских или женских голосов»: специфика интерпретации жанра}

\section{Анотація}

Днепровская Н. С. Рахманинов. «Шесть хоров для детских или женских голосов»: специфика интерпретации жанра. В статье раскрыта специфика трактовки драматургии цикла детских хоров С. Рахманинова на основе целостного анализа тематизма и образно-эмоционального строя, отмеченного возвышенно-одухотворённой лирикой. Обоснован вывод о новаторстве композитора: в этом цикле впервые автор задействовал сложившиеся в европейской традиции музыкальные темы-символы «Dies irae», «катабасис». Выявлены новые для детского жанра художественные принципы и приёмы композиторского письма, характерные и для последующих его опусов: стилевое богатство мелодики, гармонии, ритмики, фактуры, полиметрии и полиритмии, трактовки тональности, звукоизобразительность (колокола). Как результат, доказана духовно-эстетическая ценность «Шести хоров» С. Рахманинова для практики светского детского хорового исполнительства. Ключевые слова: хоровое творчество; детское хоровое пение; светская духовно-хоровая лирика; «Dies irae»; «катабасис»; колокола. 
Дніпровська Н. С. Рахманінов. «Шість хорів для дитячих або жіночих голосів»: специфіка інтерпретації жанру. В статті розкрито специфіку трактовки драматургії циклу дитячих хорів С. Рахманінова на грунті цілістного аналізу тематизму та образно-емоційного строю, позначеного піднесено-одухотвореною лірикою. Обгрунтовано висновок про новаторство композитора: зокрема, в цьому циклі вперше автор задіяв усталені в європейській традиції музичні теми-символи «Dies irae», катабасіс. Виявлено нові для дитячого жанру художні принципи та прийоми композиторського письма, характерні і для наступних його опусів: стильове багатство мелодики, гармонії, ритміки, фактури, поліметрії та поліритмії, трактування тональності, звукозображувальність (дзвони). Як наслідок, доведено духовно-естетичну цінність «Шести хорів» С. Рахманінова для практики світського дитячого хорового виконавства. Ключові слова: хорова творчість; дитяча хорова музика; світська духовно-хорова лірика; Dies irae; катабасіс, колокола.

\section{Dniprovska N. S. Rachmaninov. 'Six choirs for children's or women's voices": specific of interpretation of the genre.}

Introduction. In the article the cycle of children's choruses of S. Rachmaninov is considered, his characteristic features in subjects, figurative disclosure, the special role of lofty spiritualized lyric poetry; for the first time the appearance in the choral works of the composer of the themes "Dies irae", "katabasis"; the spiritually-aesthetic value of Rachmaninov "Six Choruses" for secular children's choral singing and performance is revealed.

"Six choirs for children's or women's voices" op. 15 were written by S. Rachmaninov in 1895 , the date of which he indicated in a letter to B. Asafiev on April 13, 1917. By the time the cycle was created, S. Rachmaninov was already the author of a considerable number of works. In the fall of 1894, he was employed by the Mariinsky Women's School as a teacher of music theory and an accompanist of the choir. Specially for the choir of students, "Six choirs for children's or women's voices" were written: 1) "Glory!", Words by N. Nekrasov; 2) "Night", words by V. Ladyzhensky; 3) "Pine", words by M. Lermontov (from G. Heine); 4) "The waves dozed off", words by K. Romanov, 5) "Captivity", words by N. Tsyganov; 6) “Angel”, words by M. Lermontov.

The features of S. Rachmaninov's musical and artistic thinking, which researchers usually note in his romances - the significant role of accompaniment 
and a simple 3-part form, having their own historical archetype in the baroque three-part aria da capo (Antipov, 2014: 9) - can be found in "Six choirs". The enormous artistic role of the piano accompaniment, its developed texture and organic unity with the score should be especially paid attention to. The vivid imagery of the cycle owes much to the instrumental part, which the composer not only went far beyond the accompaniment, but often has independent significance too. At first glance, the choral score of the cycle is uncomplicated - mainly with diatonic two-voice. But behind seeming simplicity, inexhaustible performing tasks for the choir and piano part are in favor. The extreme choral plays frame the cycle with themes of deep ethical and spiritual content that had not previously been encountered in children's choral music. The middle rooms are dominated by bright lyrics, youthfully light sadness, and harmony between the pictures of nature and the states of the human soul reigns.

No. 1 "Glory!" - the character of the work conveys pathetic, prayer (appeal to the Almighty for blessing) and lyrical-patriotic feelings. In the 3rd section of the miniatures, the accompaniment fills the music with fanfare intonations, in the last 6 beats, the dynamic tension within the framework of one tonic harmony is steadily increasing, and in the bass of the piano the bell ringing and ceremonial drum beat are imitated, completing the picture of the celebration. In No. 2 "Night", the author embodies a dreamy-contemplative mood with the help of the choral cantilena. Frettonal ambiguity of the extreme parts (major-minor), functions languidly lasting for several measures, delicate harmonic colors, flexible ligature of figures, masterful techniques of sound-visualization contribute to a special refinement of moods and miniature images and are associated with impressionist music. No. 3 "Pine" S. Rachmaninov chose M. Lermontov's translation as the theme of loneliness and dreams of happiness, giving contrast to the musical images of northern Pine and southern Palma. No. 4 "The waves dosed off" - to convey the state of spiritual harmony and dreamy peace S. Rachmaninov found a set of expressive compositional techniques. Here we emphasize the special independence of the piano part, which does not contain a choral theme, but plays an important soundvisual role, enriching the narration of the choir. No. 5 "Captivity" - the image of a gentle bird, imprisoned in a golden cage, is widespread in fairy tales and poetry of the peoples of the world, as well as in choral music. In N. Tsyganov's verses, the denouement is optimistic - the nightingale is set free. S. Rachmaninov relies intonationally on the Russian peasant cry-lamentation. The melody has a touching 
colour, the miniature is distinguished by a bright national color. No. 6 "Angel". The poem tells of the great sacrament of conception in the spiritual world of a new person's life. The Angel carries this person's soul from heaven to earth to connect it with the body of the unborn child. In flight, an Angel sings a song about celestial gardens to this yet unincarnated Soul. The composer weaves a fragment of the motive-symbol "Dies irae" into Angel's theme, entrusting it to a part of the alto and veiling from above the unrecognizabl third major second part of the soprano. The smoothly descending theme of the Soul can be described in this context as "katabasis". This symbolism gives the miniature a deep philosophical meaning.

S. Rachmaninov was the first Russian composer to create an example of concert purpose in The "Six choirs". He raised to a new level the theme of children's works, characteristic of the genre of that time. And that is education of a spiritually rich personality. The author revealed the extraordinary rhythmic and intonational richness of musical speech, the mastery of texture, harmony, the sophistication of technical techniques, and the tonal color scheme were rare for children's choral music of that time. The richness of colors and the layering of the piano part bring it closer to the orchestra.

In The "Six choirs for children's or women's voices" S. Rachmaninov revealed a new example of children's choral music for concert purposes, which has high artistic merits, a deep substantive theme, and an aesthetic and educational orientation. The composer first attracted high poetry, revealed a spiritual and moral subtext. The theme of Faith, reflected in the first and last miniatures, "rings" the cycle, like Alpha and Omega, giving special semantics and significance to its figurative content. The essay reflected important artistic principles and writing techniques, characteristic of his subsequent opuses, but new to the children's genre.

Like the First Symphony (1895), created in the same year as the cycle, the "Six choirs" for the first time include the theme "Dies irae" symbolic for S. Rachmaninoff's art, which further permeates his work up to "Symphonic dances", as well as the theme "katabasis" revealing the spiritual and philosophical meaning of the work. This cycle was S. Rachmaninov's only experience in children's choral music, in which first for the genre he embodied high spiritual and ethical ideas of a romantic artist, his Christian picture of the world, the eternal themes of love for the Fatherland, life and death, good and evil, also actual for modern society and children of the XXI century. 
Prior to S. Rachmaninov, children's choral music did not know such a depth of content, mastery of embodiment, aesthetic pleasure. The unsurpassed beauty of "Six choirs for children's or women's voices" made them a phenomenon of perfection in musical art for children, which is timeless, of course. Key words: choral work of S. Rachmaninov; children's choral music; children's choral singing; secular spiritual and choral lyrics; Dies irae; katabasis.

«Если не обратитесь и не будете как дети, не войдете в Царство Небесное...» (Мф. 18: 1-9)

Постановка проблемы. Тема детства в искусстве не входит в число его «вечных тем», как не всегда и отношение взрослых к детям было таким, как в наше время. Большую часть истории человечества ребёнок был малозаметным для старших: детство было коротким, рано начиналась трудовая жизнь. С развитием общества, от уровня духовной культуры которого зависит продолжительность детства как такового, менялось и отношение к ребёнку.

Детская хоровая музыка, ведущая свое начало от В. А. Моцарта, отпочковалась как жанр в творчестве композиторов-романтиков Р. Шумана, Ф. Мендельсона, Э. Грига. Именно в XIX в. «тема ребёнка» в литературе, живописи, музыке переросла в «тему детства» и далее распространилась на театр, оперу, балет и другие жанры. В России с развитием системы просвещения светское детское хоровое пение постепенно стало востребованным в школах и отразилось в композиторском творчестве. Раскрытию богатого и неповторимого мира детства в русской хоровой музыке уделяли внимание Н. Римский-Корсаков, Ц. Кюи, А. Гречанинов, А. Аренский, А. Лядов, Вик. Калинников. Шёл процесс формирования искусства для детей, достигшего своего расцвета в XX в. Изучение в этом контексте раннего цикла С. Рахманинова «Шесть хоров для детских или женских голосов» актуально по многим причинам.

Во-первых, в отечественном музыковедении до сих пор не дана должная оценка этого сочинения с учётом эволюции жанра детской хоровой музыки второй половины XIX века. Во-вторых, с позиции исторического опыта и установок когнитивного музыковедения 
определяется оценка опуса 15 С. Рахманинова как новаторского. В-третьих, хормейстерский опыт автора статьи подсказывает необходимость широкой популяризации этого сочинения в современном репертуаре детских хоров, что соответствует авторскому замыслу.

Обзор публикаций по теме. Научный интерес к глубокому и многомерному творчеству С. Рахманинова всегда был большим. О нём писали Б. Асафьев, В. Беляев, В. Богданов-Березовский, В. Брянцева, О. Соколова, А. Соловцов, Ю. Келдыш, А. Кандинский, В. Медушевский, Л. Скафтымова, Н. Бекетова, Е. Назайкинский, Е. Вартанова, Т. Чупахина, В. Антипов, Н. Медведева, А. Ляхович. Среди исследований множества граней и ракурсов произведений гениального композитора (в том числе хоровых) незаслуженно скромное место принадлежит циклу «Шесть хоров для детских или женских голосов», который ранее не анализировался и даже не всегда упоминался. Исключение составляют авторы В. Брянцева (1976), кратко осветившая историю создания хоров без анализа музыки, и О. Соколова (1984), лаконично охарактеризовавшая эмоциональный строй миниатюр. Целостный анализ сочинения и его значение для жанра детской хоровой музыки доныне остаются «белым пятном» в музыкознании.

Цель статьи - обосновать художественную новизну и специфику интерпретации жанра «Шести хоров для детских или женских голосов» ор. 15 С. Рахманинова на основе их целостного анализа.

Изложение основного материала. «Шесть хоров» ор. 15 написаны С. Рахманиновым в 1895 г., став его единственным опытом в жанре детской хоровой музыки. Дата создания указана автором в письме Б. Асафьеву 13 апреля 1917 г. (Асафьев). Сочинение появилось в пору творческой активности, отразив свет и радость молодости. К моменту создания цикла композитор являлся уже автором солидного числа произведений. Ещё не было горечи неудачи с Первой симфонией, в его творческом портфеле - опера «Алеко», симфония «Юношеская» (І ч.), хоровой концерт «В молитвах неусыпающую Богородицу», фантазия «Утёс», 23 романса, 32 произведения для фортепиано, Элегическое трио, Сюита и Каприччио для оркестра, квартет, сочинения для скрипки, виолончели. Обращению С. Рахманинова к детской музыке способствовал тот факт, что осенью 1894 года он 
поступил на службу в Мариинское женское училище преподавателем теории музыки и аккомпаниатором хора1. Специально для хора учениц композитором были написаны «Шесть хоров для детских или женских голосов»: 1) «Славься!», слова Н. Некрасова; 2) «Ночка», слова В. Ладыженского; 3) «Сосна», слова М. Лермонтова (из Г. Гейне); 4) «Задремали волны», слова К. Романова; 5) «Неволя», слова Н. Цыганова; 6) «Ангел», слова М. Лермонтова.

Будучи разносторонне образованным, композитор любил и хорошо знал поэзию и живопись, тщательно выбирал тексты для своих произведений. Широко известны его слова: «Помогают творчеству красота и величие природы. Меня очень вдохновляет поэзия. После музыки я больше всего люблю поэзию [...] У меня всегда под рукой стихи. Поэзия вдохновляет музыку, ибо в самой поэзии много музыки [...] После музыки и поэзии я больше всего люблю живопись» (Антипов, 2013: 7). С. Рахманинов признавался, что миниатюрные произведения ему труднее сочинять, чем симфонии и концерты, отмечал сложность исполнения «Шести хоров», «... которые, между прочим, ни одни дети не споют» (Апетян, 1978: 253).

Парадокс высказывания автора заключается в том, что хоровая партитура цикла выписана, на первый взгляд, преимущественно диатоническим двухголосием - терцовым, октавным, изредка имитационным (№ 1, 2, 4). Как исключение, встречается трехголосие на смысловых вершинах фраз (№ 1, 2, 6) и всего несколько 4-хголосных аккордов («Ангел»). Но за кажущейся простотой проступают неисчерпаемые исполнительские задачи для хора, свидетельствующие о зрелости таланта и мастерстве автора. Яркая образность цикла во многом обязана инструментальной партии, которая в этом опусе композитора не только вышла далеко за рамки аккомпанемента, но часто выразительно досказывает, «дорисовывает» повествование хора, ведёт диалог.

${ }^{1}$ В Мариинское училище принимали 280 девочек 8-10 лет из небогатых семей военных и чиновников и готовили домашних учительниц, обучая в течение 8 лет разным предметам, в том числе музыкальным. Среди инспекторов и руководителей училища были выпускники и педагоги Московского университета, известные музыканты и профессора Московской консерватории. 
Творческие принципы С. Рахманинова, обычно отмечаемые исследователями, - художественная роль сопровождения и простая 3-частная форма, имеющие свой исторический прототип в барочной арии da capo (Антипов, 2013: 9), - можно найти и в «Шести хорах». При этом необходимо особо отметить огромную роль партии фортепиано, ее развитую фактуру, органичное единство с хоровой партитурой. Крайние хоровые пьесы обрамляют цикл темами глубоко этического, духовного содержания, ранее не встречавшимися в детской хоровой музыке.

В средних номерах цикла преобладает светлая лирика, по-юношески легкая грусть, гармония между картинами природы и состояниями души человека. Все части цикла, независимо от начального характера, заканчиваются оптимистично или просветлённо.

№ 1 «Славься!» (G-dur, форма 3-частная репризная) О. Соколова называет миниатюрной кантатой (1984: 40). С. Рахманинов сочетает в ней черты приветственного канта (лапидарные фразы, диатоника крайних частей, простота функций $T-S-D-T)$ и псалмодию. Если одноименный хор М. Глинки в финале оперы «Жизнь за царя» воспел русскую землю и её народ, то эта хоровая пьеса посвящена автором императору Александру II - Освободителю. Характер музыки отражает патетические (тт. 1-11), молитвенные (обращение ко Всевышнему за благословением, тт. 12-17) и лирико-патриотические чувства (тт. 18-23). Мужественно-героический тон возникает уже в первых восклицательных репликах хора. В репризе сопровождение наполняет музыку фанфарными интонациями, в последних тактах динамическое напряжение в рамках одной тонической гармонии неуклонно нарастает, а «басы» фортепиано имитируют колокольный звон и парадный барабанный бой, завершающие картину торжества (тт. 34-37).

Возвышенно-одухотворённая лирика нашла совершенное воплощение в миниатюрах «Ночка», «Сосна», «Задремали волны», «Ангел». Так, в № $\mathbf{2}$ «Ночка» $(F-d u r)$ мечтательная созерцательность создается с помощью хоровой кантилены. На фоне неясных ночных «шорохов» во вступлении и сумеречной игры светотеней мажоро-минора тема сопрано завораживает, воздушно «зависая» в сонном оцепенении; ей тихо вторит имитация в партии альтов. В среднем разде- 
ле музыка словно «оживает», передавая радостные чувства ожидания нового дня. В репризе минорные интонации первоначальной темы автор ладово переосмысливает и «преодолевает» в сторону мажора, мастерски превращая образ Ночи в образ Зари. Интересно использование перечений в заключительной интонации, окраску которой можно сравнить с первым лучом восходящего солнца, прорезающим горизонт (граница Ночи и Дня). Ладотональная неопределённость крайних частей, томно длящиеся по нескольку тактов функции (наряду с плагальными оборотами ослабляя внутритональные тяготения), нежные гармонические краски, гибкая «вязь» фигураций, мастерские приёмы звукоизобразительности - все это способствует импрессионистической утончённости настроений миниатюры.

№ 3 «Сосна» (a-moll, простая 2-частная форма). Этот поэтический образ не раз привлекал внимание композиторов и живописцев (А. Даргомыжский, С. Танеев, И. Шишкин). Из нескольких переводов Г. Гейне С. Рахманинов избрал не любовную лирику Ф. Тютчева или А. Фета (Кедр-Пальма), а тему одиночества и мечты о счастье в стихотворении М. Лермонтова, создав контраст музыкальных образов северной Сосны и южной Пальмы. Отметим особенности музыкального воплощения образа Сосны: минор, ритмически и интонационно заострённая «колючая» октавно-унисонная фраза хора и сопровождения «На севере диком стоит одиноко», после которой мелодия исчезает, уступая место дремотным репликам с «покачиванием» хоровых аккордов, как в колыбельной (тт. 8-12, «и дремлет, качаясь»), под порывы «жестоких ледяных ветров» в фортепианных басах. Создаётся впечатление стремящегося наружу чувства, скованного вечным холодом, обретающего драматическую окраску. «Лишённая» мелодии музыка вселяет ощущение тревоги, беззащитности. Звучание хора в хроматических секвенциях «сползает» вниз, словно «погружая» образ Сосны в глубокий сон.

Музыкальная стилистика Пальмы: в сопоставлении появляется контрастный одноименный мажор, партия хора остается декламационной; «художественной кистью» композитора становится партия фортепиано («пение на рояле» тембрами среднего и высокого регистров). Чувственная тема сопровождения, хроматизированная кружениями 
звуков, словно восточной вязью, устремлена ввысь на фоне средних голосов, взволнованно пульсирующих, как сердце, (тт. 16-25). Грёзы мятущейся души находят просветление с появлением мелодии в заключительной фразе «прекрасная пальма растёт».

№ 4 «Задремали волны» ( $D$-dur, куплетно-вариантная форма) певучая, светлая, поэтична музыка. Для передачи состояния душевной гармонии, безмятежности и мечтательного покоя С. Рахманинов нашёл комплекс выразительных приёмов. Водному пейзажу придает зыбкость тональная неопределённость переменного лада $D-h$ от начала до конца миниатюры, волнообразное движение мелодии в партии хора с ходами на тритоны, увеличенные и уменьшённые интервалы, полиритмия между хором и сопровождением. Подчеркнём самостоятельность партии фортепиано, которая в этой пьесе играет важную звукоизобразительную функцию, «расцвечивая» и обогащая повествование хора. Тематизм фортепиано характеризуется прозрачной фактурой на основе остинатности, «всплесками» арпеджированных аккордов, «игрой воды» в виде «переливчатой» ладовости параллельного мажоро-минора, «качающейся» триольной пульсации, «волнением» мелких фигураций. Благодаря этим приёмам тема-образ имеет признаки баркаролы, вместе с тем, общая умиротворяющая гармоничность придаёт черты колыбельной.

№ 5 «Неволя» ( $F d u r$, форма сложная 3-частная репризная) образ нежной птицы, заточённой в золотую клетку, широко распространён в сказках и поэзии народов мира, а также в хоровой музыке, например: 3. Кодаи «День за окном лучится», Г. Свиридов «Курские песни» (№ 6 «Соловей мой смутный»). В стихах А. Цыганова развязка сюжета по-славянски оптимистична: соловья отпускают на волю. Раскрывая смысл и идя за ритмом стиха, С. Рахманинов опирается в интонационном плане на русский крестьянский плач-причёт. Хоровая тема имеет трогательную окраску, которую придают эмоциональное развёртывание волнообразных попевок, декламационность, частые паузы-вздохи, дополненные в сопровождении полутоновыми синкопами. Миниатюра отличается национальным колоритом благодаря опоре на переменность лада $F-d$, неквадратному строению фраз (3+3 т. - признак причёта), модальности, отража- 
ющей стилизацию архаики в тексте - «соловеюшка», «головушка». Хоровые голоса и партия фортепиано, дополняя друг друга, образуют эпически сдержанную, полную внутренних переживаний звуковую ткань.

№ 6 «Ангел» ( $E d u r$, форма сложная 3-частная репризная) - произведение, в котором помимо пейзажной лирики отразилась духовная сторона устремлений композитора. Вслед за М. Лермонтовым и П. Чайковским, любимыми С. Рахманинова в 90-е годы, он размышляет о жизни и смерти. Стихотворение повествует о великом таинстве зачатия в духовном мире жизни нового человека, душу которого Ангел несёт с небес на землю, чтобы соединить с телом будущего ребёнка. В полёте Ангел поёт этой, еще не воплотившейся Душе песню о небесных садах. Его неземная песня - как «сладкое погружение в тихие райские звуки, которые невозможно ни доподлинно припомнить, ни забыть» (Горецкий).

Миниатюра захватывает светлой жизнеутверждающей силой: это гимн небесам и наставление о земном бытии как способе заслужить право вернуться туда, достойно пройдя жизненные испытания. С. Рахманинов создал арсенал выразительных приёмов, передающих безмятежный ночной пейзаж, на фоне которого Ангел в полёте баюкает Душу: нежная тема 1-й части в духе колыбельной на фоне остинатно-пульсирующего сопровождения, ажурных фигураций фортепиано, «окутывающих» мелодию. В тему Ангела композитор вплетает сегмент мотива-символа «Dies irae», поручая её партии альтов и вуалируя до неузнаваемости мажорной терцовой верхней второй в партии сопрано (см. пример 1).

В кульминации второго раздела тема Dies irae проводится одновременно в партии хора и в сопровождении, но в полиритмии и канонической имитации, отчего она звучит особенно настойчиво (пример 2). Ангел несёт Душу «в объятиях»- уже в одном этом слове заключена божественная любовь Всевышнего к своему творению! Далее она отражена в фактуре переплетением тем Ангела и Души, в диалогичности хора и сопровождения. Таким образом, пьеса построена на двух темах - Dies irae и катабасис - в их взаимодействии и соединении в репризе (пример 3). 
Нисходящая тема Души «катабасис» ассоциирует спуск с неба на землю, и в то же время символизирует краткость времени пребывания человека на земле. Тональный план хоровой пьесы содержит нисхождение по полутонам (подчёркнуто на схеме): $\boldsymbol{E}-\boldsymbol{c i s}-\boldsymbol{E}-\boldsymbol{A s}-$ $\underline{G}-\boldsymbol{F i s}-\boldsymbol{F}-\boldsymbol{E}$.

Если в произведениях, созданных С. Рахманиновым в XX в., тема «Dies irae» - символ Страшного суда, чем дальше, тем настойчивее будет будоражить слушателя предчувствием катастрофы, Апокалипсиса человечества, то в «Ангеле» она воспринимается пока лишь как назидание юным: «Помни!». Катабасис - грозный символ нисхождения в смерть - в «Ангеле» тоже не страшит, а скорее наставляет. Это один из тех случаев в музыке, о которых В. Медушевский пишет, что «смерть уже не пугает, ибо побеждена» (Медушевский). Она преодолена крестной жертвой Спасителя, Его божественной любовью к человеку и даром воскресения.

$\mathrm{B}$ драматургии этой хоровой пьесы кульминации имеют точечный характер; полнозвучной подготовленной кульминацией является кода сопровождения, где неустанно пульсировавший ритм секстолей-остинато неожиданно останавливается. «Полёт» окончен: в широких величественных аккордах партии фортепиано озвучено высочайшее «таинство вдыхания» новой жизни в нового человека.

С. Рахманинов прекрасно слышит «музыку стиха»: отсюда в «Шести хорах» тонкое следование оттенкам поэтической фразы, необычайное ритмо-интонационное богатство музыкальной речи, дивная по красоте гармония, фактура. Как и в других его сочинениях, здесь проявился неповторимый мелодический дар композитора в раскрытии слова: широкая распевность, тонкая интонационная выразительность, эмоциональная наполненность и «скрытая сила» каждого тона. Б. Асафьев вспоминал слова Ф. М. Блуменфельда: «... Кто их знает - Шаляпин ему или он (Рахманинов) Шаляпину внушил секрет одухотворённости любого интервала». И далее: «И в самом деле, не было ни одной неведомой обоим тропы на путях интервалов, которая не вела бы к осмысленнейшему - эмоционально и интеллектуально - “произнесению”. Очевидно, для них обоих мелодическое в музыке и было всем - ключом к человечнейшему в звуках» (Асафьев). 
Использование автором мажора (№№ 1, 2, 4-6) или его утверждение в конце минорной пьесы (№ 3), устремлённость мелодий вверх (№№ 1-3, 5, 6), окончания фраз и периодов на терциях гармоний (№№ 1, 4-6) - придают музыке ощущение романтической приподнятости, душевного света, радости бытия. Блестящий мелодист, С. Рахманинов мог и отказаться от мелодии, заменив ее хоровой декламацией (№ 3). Смена тональности происходит здесь чаще не через побочную $D$, а через сопоставление, мелодико-гармоническую модуляцию или секвентное развитие (№ 1-6, средние разделы).

Миниатюры расположены по принципу контраста и ярко индивидуальны по способу изложения. Их драматургия раскрывает образы в динамике, в музыкальных формах нет ни одного буквального повтора; разнообразие способов развития поражает. Сочинение отличает редкое для детской хоровой музыки того времени мастерство фактуры, изысканность приёмов, ладотональной колористики, полиметрия (наложение дуольной пульсации размера 4/4 хоровой партитуры на триольную пульсацию 12/8 в сопровождении № 6) и полиритмия (№ 1-4). Богатство красок, звукоизобразительность, фактурная многослойность партии фортепиано приближают его к оркестровому звучанию. Обратим внимание и на детальную разработанность агогики, фразировки, градации оттенков (от fff до рppp). Например, в тексте «Сосны», состоящем из 33 тактов, прописаны 42 (!) исполнительские ремарки.

В отличие от детской хоровой музыки Ц. Кюи, Н. Римского-Корсакова, рассчитанной на камерное исполнение, С. Рахманинов первым из русских композиторов создал в «Шести хорах» образец концертного предназначения. Среди его современников стремление наследовать отдельные идейно-композиционные принципы этого цикла отмечается в творчестве для детей Р. Глиэра. В то время как А. Гречанинов, А. Лядов искали свои пути, А. Аренский, Вик. Калинников, М. Анцев продолжали создавать детскую музыку, не выходя далеко из круга образов и тематики представителей старшего поколения - Ц. Кюи и Н. Римского-Корсакова.

В «Шести хорах» отчётливо проявилась высота нравственных принципов С. Рахманинова. Тематику детства, характерную для 
жанра в искусстве второй половины XIX в. (иллюстрации дня, прогулки, природа, сказки, игры ребенка) композитор поднял на иной уровень - воспитания духовно богатой личности. Известны слова С. Рахманинова: «Музыка прежде всего должна быть любима; должна идти от сердца и быть обращена к сердцу. Иначе музыку надо лишить надежды быть вечным и нетленным искусством» (Апетян, 1973: 103). Согласно мысли В. Медушевского, «Призвание светской музыки, как сферы православной культуры общества, есть проповедь на паперти, в которой духовно осмысливаются и молитвенно омываются все области жизни» (Медушевский). Эту «проповедь» для детей и осуществил в своём светском шедевре С. Рахманинов.

Выводы. В контексте музыкальной культуры конца XIX - начала XX веков С. Рахманинов явил новый образец детской хоровой музыки концертного предназначения, имеющий глубокую содержательность, этическую направленность. В «Шести хорах для детских или женских голосов» композитор впервые привлёк поэзию Н. Некрасова, М. Лермонтова, К. Романова. Тема природы, ранее воплотившаяся в творчестве для детей Ц. Кюи, у С. Рахманинова тесно сопряжена с духовно-нравственным подтекстом. Как истинно православный художник, С. Рахманинов воплотил христианские идеи в светском хоровом произведении для детей. Тема Веры, отражённая в первой и заключительной миниатюрах, «окольцовывает» цикл, как альфа и омега, придавая смысловую цельность его образному содержанию. Автор не использует песенную форму, не упрощает и «не приспосабливается» к детям, а говорит с ними на языке своего времени, соответствующем ценностной семантике высокой поэзии.

В сочинении 22-летнего автора, как в капле воды, отразились важные художественные принципы и приёмы композиторского письма, характерные и для последующих его опусов, но новые для детского жанра: богатство мелодики, гармонии, ритмики, фактуры, полиметрии, полиритмии, расширенной тональности, приёмов звукоизобразительности, в том числе, имитации колоколов. Как и Первая симфония, созданная в один год с циклом (1895), «Шесть хоров» впервые включают знаковую для искусства С. Рахманинова тему Dies irae, пронизывающую его творчество вплоть до «Симфонических танцев», 
а также тему «катабасис» для раскрытия философского замысла сочинения.

Цикл стал единственным опытом С. Рахманинова в жанре детской хоровой музыке, в котором он впервые воплотил высокие духовно-этические идеи художника-романтика, христианскую картину мира, вечные темы любви к Отечеству, жизни и смерти, добра и зла, актуальные для современного общества. Детская хоровая музыка до С. Рахманинова такой глубины содержания, мастерства воплощения, эстетического наслаждения не знала! Непревзойдённая красота «Шести хоров», способная менять мир к лучшему, сделала их феноменом совершенства в хоровом искусстве для детей, неподвластным времени, устремлённым через детей в будущее.

\section{ЛИТЕРАТУРА (REFERENCES)}

Антипов, В. И. (2014). Рахманинов и мировая культура. С. В. Рахманинов и мировая культура, 3-13.

Antipov, V. I. (2014). Rakhmaninov i mirovaya kultura. S. V. Rakhmaninov i mirovaya kultura [Rachmaninoff and world culture]. 3-13 [in Russian].

Асафьев, Б. В. С. В. Рахманинов. Retrieved from https://senar.ru/memoirs/ Asafiev/\#op28

Asafev, B. V. S. V. Rakhmaninov. [S. V. Rachmaninov]. Retrieved from https:// senar.ru/memoirs/Asafiev/\#op28

Брянцева, В. Н. (1976). С. В. Рахманинов. Москва: Сов. комп., 645.

Bryantseva, V. N. (1976). S. V. Rakhmaninov. [S. V. Rachmaninov]. Moskva: Sov. komp., 645 [in Russian].

Горецкий, Я. «Лермонтовский сюжет» в жизни и творчестве Рахманинова. Retrieved from http://docplayer.ru/26402418-Lermontovskiy-syuzhet-vzhizni-i-tvorchestve-rahmaninova.html

Goretskiy, Ya. «Lermontovskiy syuzhet» v zhizni i tvorchestve Rakhmaninova ["Lermontov's plot" in the life and work of Rachmaninov]. Retrieved from http://docplayer.ru/26402418-Lermontovskiy-syuzhet-v-zhizni-i-tvorchestverahmaninova.html

Медушевский, В. В. Отражение молитвенного опыта в шедеврах светской музыки. Retrieved from https://www.portal-slovo.ru/art/36056.php 
Medushevskiy, V. V. Otrazhenie molitvennogo opyta v shedevrakh svetskoy muzyki [Reflection of prayer experience in the masterpieces of secular music] Retrieved from https://www.portal-slovo.ru/art/36056.php

Рахманинов, С. В. (1978). Литературное наследие в 3 m. Т. 1. Москва: Сов. комп., 648.

Rakhmaninov, S. V. (1978). Literaturnoe nasledie v 3 t. T. 1. [Literary heritage in 3 tons. T. 1]. Moskva: Sov. komp., 648 [in Russian].

Рахманинов, С. В. (1973). Музыка должна идти от сердца (Интервью с Дэвидом Иуеном). Советская музыка. 4. 103.

Rakhmaninov, S. V. (1973). Muzyka dolzhna idti ot serdtsa (Intervyu s Devidom Iuenom). [Music must come from the heart (Interview with David Iwen)]. Sovetskaya muzyka, 4. 103 [in Russian].

Соколова, О. И. (1984). Сергей Васильевич Рахманинов. Москва: «Музыка», 160.

Sokolova, O. S. (1984). Sergey Vasilevich Rakhmaninov [Sergey Vasilevich Rachmaninov]. Moskva: «Muzyka», 160 [in Russian].

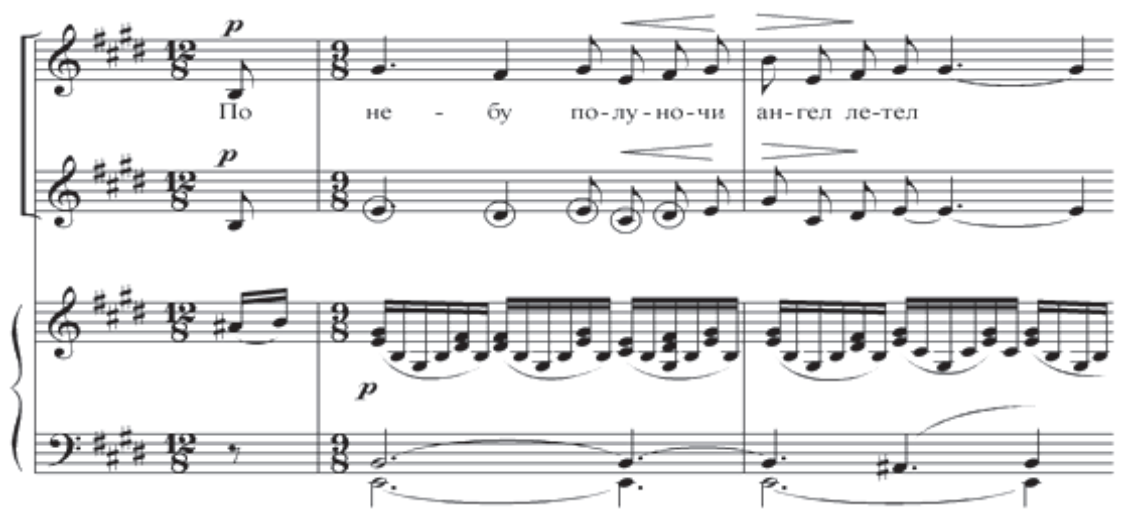

Пример 1.«Ангел», m.m. 3-4 


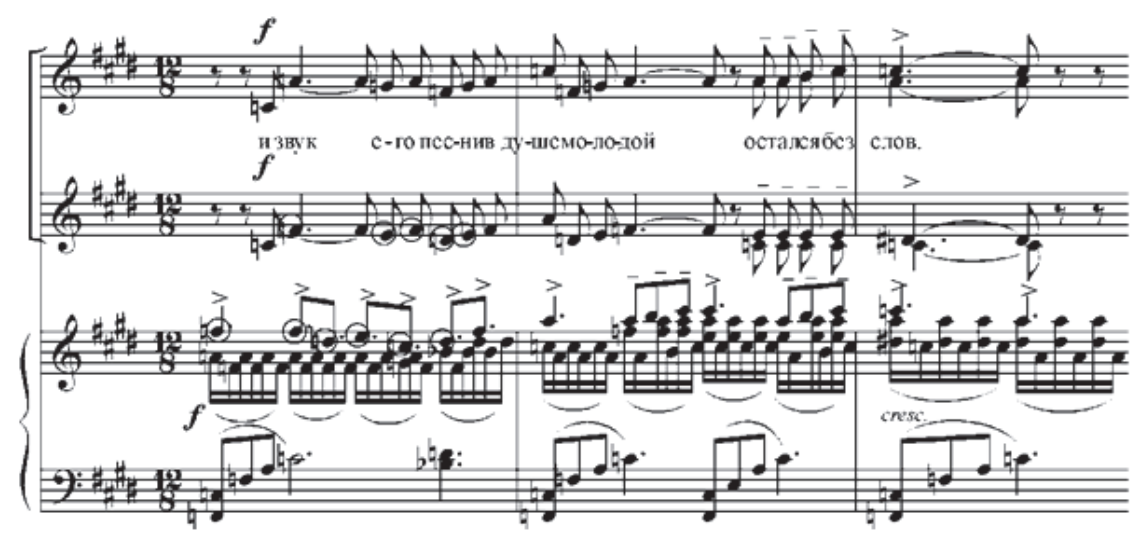

Пример 2. «Ангел», m.m. 27-29

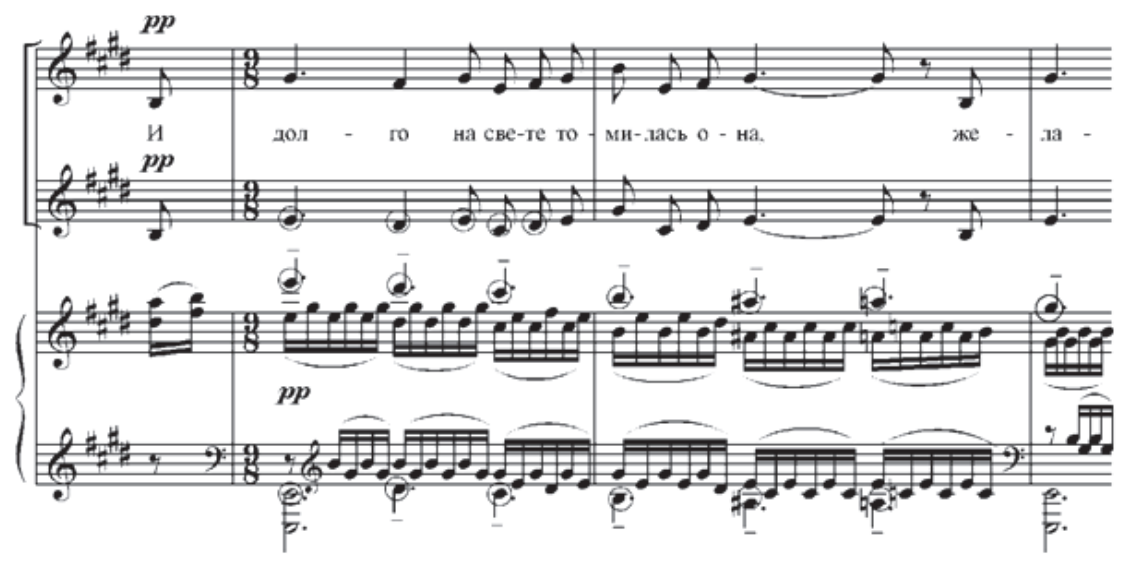

Пример 3. «Ангел», m.m. 32-34 